\title{
Russia’s New Asian Tilt: How Much Does Economy Matter?
}

\author{
Roman Vakulchuk
}

\begin{abstract}
The economic development of Russia's Far East has been proclaimed a policy priority, to be facilitated by an ambitious turn or 'pivot' to Asia. This chapter assesses Russia's economic reorientation towards Asia, offering an overview of the Far Eastern dimension of Russia's economic relations with its major Asian partners in 2010-16, based on analysis of the dynamics of investment, trade relations and business climate development. Since 2014, trade with Asian partners has stagnated, while foreign investment (except for Chinese) has remained negligible. Moreover, trade is still mainly oriented towards markets in European Russia. The chapter concludes that Russia's pivot to Asia has not yet become an economic pivot - and that such a turn would be more easily attainable under a non-sanctions regime.
\end{abstract}

Keywords Russian Far East - Trade • Foreign direct investment Sanctions • Business climate

R. Vakulchuk $(\bowtie)$

Research Group on Russia, Eurasia and the Arctic, Norwegian Institute of International Affairs, Oslo, Norway

(C) The Author(s) 2018

H. Blakkisrud, E. Wilson Rowe (eds.), Russia's Turn to the East, Global Reordering, https://doi.org/10.1007/978-3-319-69790-1_8 
The economic development of Russia's Far East has been announced as a policy priority, to be facilitated by an ambitious pivot to Asia. In 2015, speaking at the first Eastern Economic Forum in Vladivostok, President Vladimir Putin pointed out that the Russian Far East is a key region for Russia's development and 'a region that should be effectively integrated into the developing Asia-Pacific region as a whole' (Kremlin.ru 2015). At the second Forum, in September 2016, ideas about developing an 'Energy Super Ring' (to involve China, Japan, Mongolia, Russia and South Korea) and turning Vladivostok into Russia's 'San Francisco' were discussed (Russia Direct 2016a; Zubacheva 2016). Russian officials have also repeatedly declared that the government hopes to strengthen economic ties with China, Japan and South Korea. But how credible is Russia's commitment to reorient itself economically towards Asia?

The first official announcements about an imminent Russian pivot to Asia were made in connection with the adoption of the 2009 'Strategy for the Socioeconomic Development of the Far East and Baikal Region until 2025' (Vl.ru 2010; Sakai 2015). Since 2014, this policy has been further stimulated by such factors as the Western economic sanctions, falling oil prices and domestic economic decline in Russia. The sanctions introduced by the USA and the European Union in connection with the Ukraine crisis have served to separate Russia from the West, accelerating a reorientation of economic and foreign policy, as well as diplomatic relations, towards the East (Dave 2016; Gabuev 2016a).

After nearly three years of Western sanctions and Russian efforts to redirect trade, we can conclude that Moscow has only partly succeeded in this endeavour. As will be shown below, Moscow's attempts to turn eastwards have led to the emergence of new complexities and contradictions related to economic governance in the Russian Far East as well as in Russia's relations with its Asian neighbours. Moreover, China has not lived up to Moscow's expectations regarding investment (Russia Today 2016).

In this chapter I assess the Russian participation-or lack thereof-in the growing Asia-Pacific economies, and offer an overview of the Far Eastern dimension of Russia's economic relations with its major Asian partners in 2010-16. ${ }^{1}$ I discuss the dynamics of investment and trade relations and also reflect on Russia's changing economic priorities before and after 'Crimea', with a focus on implications for Russia-Asia relations in the Russian Far East. The analysis draws on secondary data, supplemented by ten expert interviews conducted in order to identify nascent trends and possible future trajectories. ${ }^{2}$ 
My main argument is that Russia's pivot to Asia has not yet become an economic one. Further, I hold that pivoting would have been easier and more attainable earlier: the Ukraine crisis and the subsequent international sanctions regime have complicated, rather than facilitated, Russia's economic turn to the East.

\section{Context Does Matter}

The Russian Far East has for decades been recognized as a region of unfulfilled promise and potential (Bradshaw 2012). The region has continued to project largely the same overall trends throughout the period under scrutiny here. Natural population growth has remained negative and outmigration high, and demographic decline continues to slow economic development (Belenets 2016). Other factors with negative impacts on the region's economic development are geography (huge uninhabited territories), harsh weather conditions (making investments more costly), lack of infrastructure (poorly developed road network, etc.), the limited capacity of Russia's railways (the main east-west transport artery) and insufficient labour resources (Sakai 2015, p.128; East Russia Magazine 2015).

Five main factors shape the context of the Russian Far East's integration into Asian markets: the international sanctions regime, Russia's prioritization of economic openness versus import substitution, economic infrastructure, continued reliance on energy as the major driver of economic development and the business climate. Taken together, these factors create a complicated environment for domestic and foreign investors to engage economically with the region on a scale in line with the ambitious goals and objectives set by the Kremlin.

First, the impact of sanctions on the development of the Russian Far East has been significant, not least because the USA and other Western countries were active investors in the region prior to 2014. And yet, despite the sanctions, Western countries continue to be important players in terms of foreign direct investment (FDI). In fact, the size of Western investment in the Russian Far East in 2014-15 was comparable to that of all East Asian countries taken together (see Fig. 8.3).

Second, Russia's countersanction measures and the introduction of import substitution policies have negatively affected the Russian Far East. Since 2014, import substitution has constituted an integral part of Russian industrial policy (WTO 2016). Moscow's import substitution plan foresees the implementation of no less than 2059 projects across 19 sectors of 
the economy between 2016 and 2020 (Edovina and Shapovalov 2015). State incentives for import substitution-such as infrastructure grants, tax breaks and preferential domestic treatment in government procurement contracts-are held to have a perverting effect on the economy:

This [import substitution] has concretely translated into the subsidization of many sectors of economic activity ... These policies ... have not brought more trade or growth to Russia. Neither have they increase [sic] product quality or lowered prices to Russian consumers. Far from it, they have introduced an economic and trade environment distant from the principles and spirit underpinning the WTO and global economic cooperation. (European Union External Action 2016)

In their assessment of Russia's import substitution policy, Richard Connolly and Philip Hanson characterize the plan as 'Soviet style'—which in their view 'raises doubts about the reality that lies behind it' (Connolly and Hanson 2016, p.2). In any case, Moscow's attempts to open up the Russian Far East to foreign investment, including turning Vladivostok into Russia's 'San Francisco', are undermined by the simultaneous introduction of import substitution policies, which in practice means pursuing greater economic isolation.

Russian economist Sergei Guriev (2015) has argued that import substitution is part of Russia's ongoing 'de-globalization'. However, while import substitution complicates access for foreign investors in the Russian Far East, it does not rule out inward FDI. What it does imply is that foreign firms that plan to invest in the 19 affected sectors are now required to 'localize' their production instead of simply exporting their products to Russia (Connolly and Hanson 2016, p.21). This inherent tension between openness and import substitution complicates economic governance in the Russian Far East and has negative implications for policy coordination among various ministries and public agencies, as we shall see.

Third, the challenges related to integrating the Russian economy in the Asia-Pacific markets are in many ways insurmountable (Russia Direct $2016 \mathrm{~b}$ ). If the sanctions were to be lifted, it would be much easier for Russia to reintegrate economically with Western markets than to achieve substantial progress in the Asia-Pacific markets. The combination of underdeveloped infrastructure, demographic challenges and lack of skilled labour in the Russian Far East as compared to in the western part of Russia all speak in favour of reintegrating with the West rather than pivoting to 
the East. Moreover, after the Ukraine crisis, the Russian government has prioritized boosting infrastructure development in Crimea (Jeh et al. 2015 , p.6). This has put substantial pressure on the federal budget. For instance, the construction of a bridge that would connect the Russian mainland with the Crimean Peninsula is estimated to cost USD 3.2-4.3 billion (Choi 2016). With the economy struggling and the shift in priorities, the budget for the development of the Russian Far East has had to take cuts - and that undermines the chances for successful realization of the eastward pivot.

Fourth, energy remains the main attraction for foreign investors in the Russian Far East (Zubacheva 2016). Also domestic energy actors such as Rosneft, Gazprom, Transneft and RusHydro have become increasingly interested in developing the region. As one local expert explained, in Russia, state investment follows large energy companies and this places constraints on significant investment in other, non-energy industries' ${ }^{3}$

The fifth factor, the development of the business climate in the Russian Far East, requires special attention. To this I return in the next section.

Overall, the Russian Far East serves as a clear example of how Russia's external economic constraints and limited domestic policy options have hindered regional economic development. While Moscow stresses the goal of becoming economically self-sufficient through import substitution policies, it cannot deny the fact that foreign investors will have to play an important role in the process of developing the Russian Far East. As shown in the next section, however, realization of the ambitious goal of transforming the Russian Far East into an attractive destination for foreign investors has yet to materialize.

\section{Attempts to Improve Business Climate in the Far East: New EfForts, Old Story?}

Improving the business climate plays an important role in facilitating Russia's turn to Asia. At the 2016 Eastern Economic Forum in Vladivostok, Iurii Trutnev, Presidential Plenipotentiary to the Far Eastern Federal Okrug, announced that economic development would be spurred with the help of preferential tariffs and administrative procedures aimed at attracting foreign investors.

Assessing the progress in business climate development after 2014, we should note that much has been done in developing hard infrastructure 
for attracting FDI. Most importantly, the government has introduced a special investment regime, the 'advanced special economic zones' (ASEZs) (territorii operezhaiushchego razvitiia). As of December 2016, 14 such ASEZs had been established in the region. Each ASEZ specializes in one or two sectors. ${ }^{4}$ The goal is to introduce one or two ASEZs in each of the nine federal subjects in the Russian Far East, to ensure balanced distribution of economic activities (see Min and Kang, Chap. 4 , this volume). ${ }^{5}$

The process of developing ASEZs is closely linked to the parallel introduction of the Free Port of Vladivostok. The latter project, adopted in 2015, brings together 15 municipalities in the southern part of Primorskii Krai that will enjoy special tax and customs privileges (East Russia Magazine 2015; see also Troyakova, Chap. 3, this volume).

To control and supervise the work of the ASEZs and the Free Port, Moscow has created a series of new administrative bodies (East Russia Magazine 2015):

- the Department for Advanced Special Economic Zones and Free Port of Vladivostok under the Ministry for the Development of the Far East (the Ministry itself was established in 2012)

- the Far East Human Capital Development Agency (aimed at attracting skilled labour and facilitating relocation to the Far East)

- the Far East Investment and Export Agency (responsible for drafting investor proposals and identifying new ASEZ residents)

- regional investment development agencies in every region of the Far East

However, most of the experts interviewed for this study held that this new bureaucratic mechanism was bulky and with a multi-layered management structure, complicating the coordination of the ASEZs. Vaguely defined and overlapping responsibilities and decision-making power among the various agencies add to the problem. These challenges spring out of the more fundamental problem of the absence of a unified strategy for the economic development of the Russian Far East and what role the Asian factor is intended to play in this (Russia Direct 2016b).

Despite attempts to make the Russian Far East, and Vladivostok in particular, an attractive place for investment, thus far, there seems to have been little significant improvement, let alone a breakthrough, in the business climate. A 2012 World Bank study ranked Vladivostok as 15 among 30 major Russian cities in terms of ease of doing business. ${ }^{6}$ Khabarovsk 
and Yakutsk were ranked even lower, 23rd and 28th, respectively. In a 2014 survey of the investment climate in 21 Russian regions, Khabarovsk and Sakha received the second-lowest rating and Primorye the lowest (Lee and Lukin 2015 , p.50). The situation has not changed dramatically since then. To the contrary, according to Igor Makarov, general perceptions of the business climate have worsened since 2014 due to the overall economic stagnation and Russia's 'precarious international political standing' (Makarov 2017, p.92). This sends a signal to domestic and foreign investors that, despite the introduction of numerous measures aimed at making the Russian Far East an attractive business destination, realities on the ground have not changed much. ${ }^{7}$

Interestingly, up to 2014, Russia compared itself mainly to Western countries as regards business climate and ease of doing business: now Moscow has begun looking towards its Asian neighbours and trade partners (China, Japan, Singapore and South Korea) (Ministry for the Development of the Far East 2016). This shift could be seen as a signal to Asian governments and investors that Russia is genuinely interested in learning from Asian experiences. However, several experts interviewed for this study share the view that the federal and local authorities have failed to communicate effectively to potential investors the changes introduced in the regulatory regime. For instance, the website of the Ministry for the Development of the Far East devoted to advanced special economic zones is all in Russian, with no translations provided. ${ }^{8}$ Moreover, the government has not involved international organizations such as the World Bank in independent, external assessments of the measures undertaken to improve the investment climate. Federal and regional public agencies remain the main source of information for potential foreign investors; there are no impartial sources to consult.

The interviews conducted for this study revealed two major obstacles to attracting FDI after 2014. First, several interviewees held that, although Russia has placed considerable focus on developing hard infrastructure (building roads, establishing special economic zones, etc.), the authorities have largely disregarded the soft infrastructure needs in the Russian Far East. For instance, in order to serve an ASEZ, officials and bureaucrats, local businesspeople and service providers need to know and understand the new rules and regulations. However, they receive little training, and still lack capacity to manage the newly established institutions.

Second, prior to developing the ASEZs, little analysis was undertaken to explore what sectors or products would be relevant for Asian markets. 
Thus, ASEZs are largely oriented towards domestic economic needs that are of little interest to foreign investors. As noted by one local expert, 'the structure of ASEZs is a clone of previous initiatives having no or little value to regional markets and global value chains'. ${ }^{9}$ Furthermore, current trends in Asian markets for goods and services indicate decreasing demand for Russian exports of raw materials (Makarov 2017, p.92). Instead, they point to the development of consumer- and service-oriented economiessectors where the Russian Far East, and Russia in general, have limited potential for exports at present. Thus, the business climate and the ASEZ regime have remained largely inward oriented, limiting the attractiveness for foreign investors and, accordingly, the flow of FDI into the Russian Far East.

\section{Trade: Who Is at the Helm?}

China, Japan and South Korea are the main trade partners of the Russian Far East, with 80 per cent of the region's total trade in 2014 (Turovskii 2015). However, since 2014, exports and imports between the Russian Far East and China, Japan and South Korea have stagnated in volume and declined significantly in value (see Fig. 8.1 for imports and Fig. 8.2 for exports). In terms of trade, China, Japan and South Korea are clearly

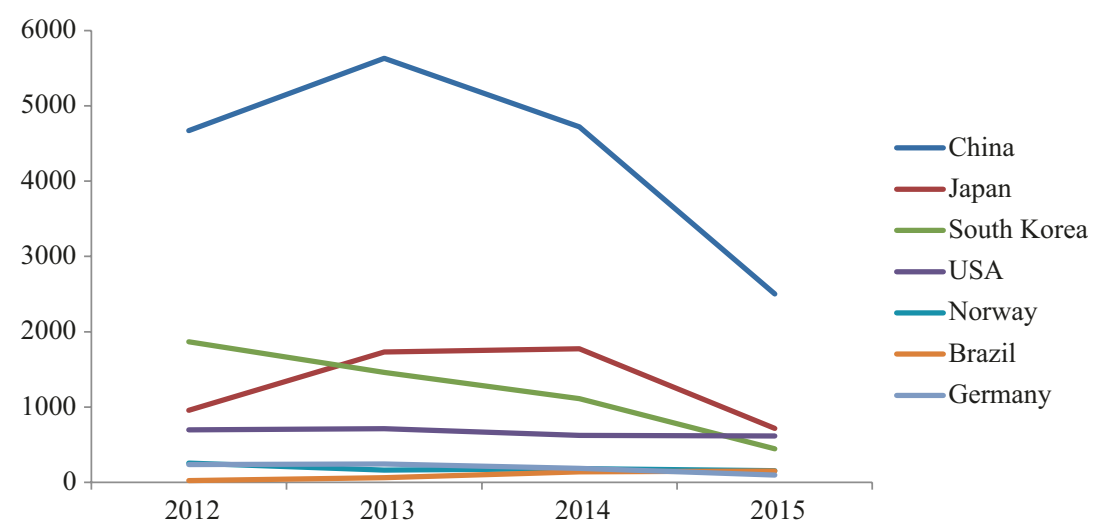

Fig. 8.1 Imports to the Russian Far East from main Asian and non-Asian trade partners (million USD) (Source: Federal State Statistics Service 2016) 


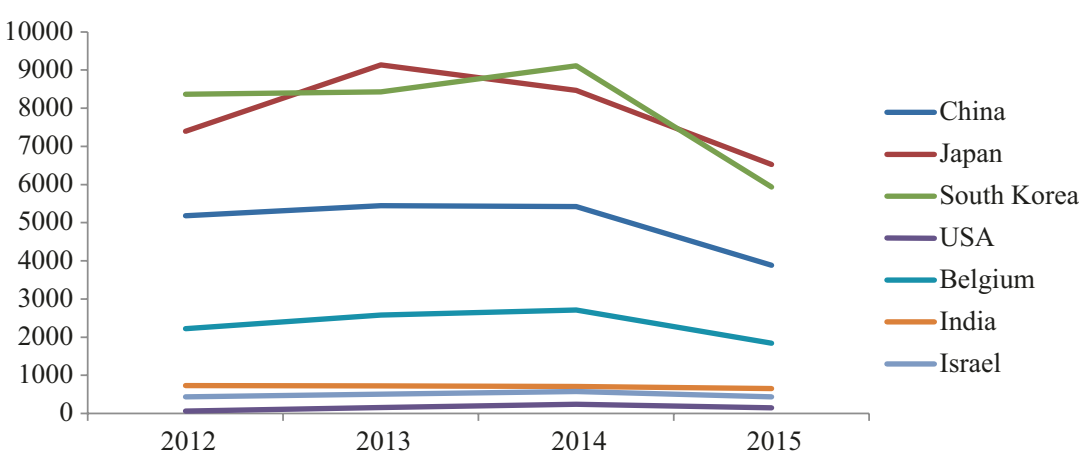

Fig. 8.2 Exports from the Russian Far East to main Asian and non-Asian trade partners (million USD) (Source: Federal State Statistics Service 2016)

ahead of the West, both before and after 2014. The biggest Western exporter is the USA, followed by Norway, Brazil and Germany, while Belgium is by far the biggest Western importer from the region. Interestingly, in terms of value, Far Eastern imports from the West remained stable across 2014-it is the main Asian trade partners that have suffered the most in the Far East.

On the national level, China remains Moscow's biggest trade partner. In 2015, its share in Russia's total foreign trade amounted to 11 per cent (Dave 2016). However, several of the experts interviewed for this study noted that the Russian political elite is concerned about China's current relatively passive position on trade, FDI and cross-border economic collaboration. In practice, they argue, China was more active in developing economic ties before the Western sanctions were introduced.

In 2015 , total Chinese exports to Russia decreased by 34.4 per cent, as compared to a 6.8 per cent increase in 2014 (The Moscow Times 2016). The ambitious goal adopted in 2011 by the Chinese and Russian governments, of achieving an annual total trade turnover of USD 100 billion by 2015 , proved unrealistic - in fact, turnover in the latter year amounted to USD 64.2 billion. A foreseen double increase by 2020 today seems even more out of reach, given the current stagnation in trade relations between the two countries, the struggling Russian economy and slower economic growth in China. ${ }^{10}$ 


\section{FDI in the Russian Far EAst}

FDI trends in the Russian Far East largely reflect the FDI situation in Russia as a whole. However, as pointed out by Rensselaer Lee and Artyom Lukin (2015), it is sometimes difficult to determine the exact level of regional FDI: the general picture may be distorted due to transactions being counted as central, not regional. In addition, the Federal State Statistics Service publishes data for FDI at the regional level, hereunder the Russian Far East, with a time lag, as compared to its statistics for the total FDI in Russia by individual countries. This further complicates analysis of post-Crimea FDI.

In general, FDI does not exceed 10 per cent of total investments in the Russian Far East: around 90 per cent of investments continue to stem from domestic investors (Labykin 2014). The volume of FDI has, however, been less affected by the international sanctions and the economic slump than is the case with trade: while total trade since 2014 has declined dramatically, total FDI in the region appears to have taken less of a hit. Figure 8.3 shows FDI trends by country over time. We see that total FDI after 2014 from the main Western investors (the Netherlands, Germany and Austria) decreased somewhat, whereas FDI from Japan and South

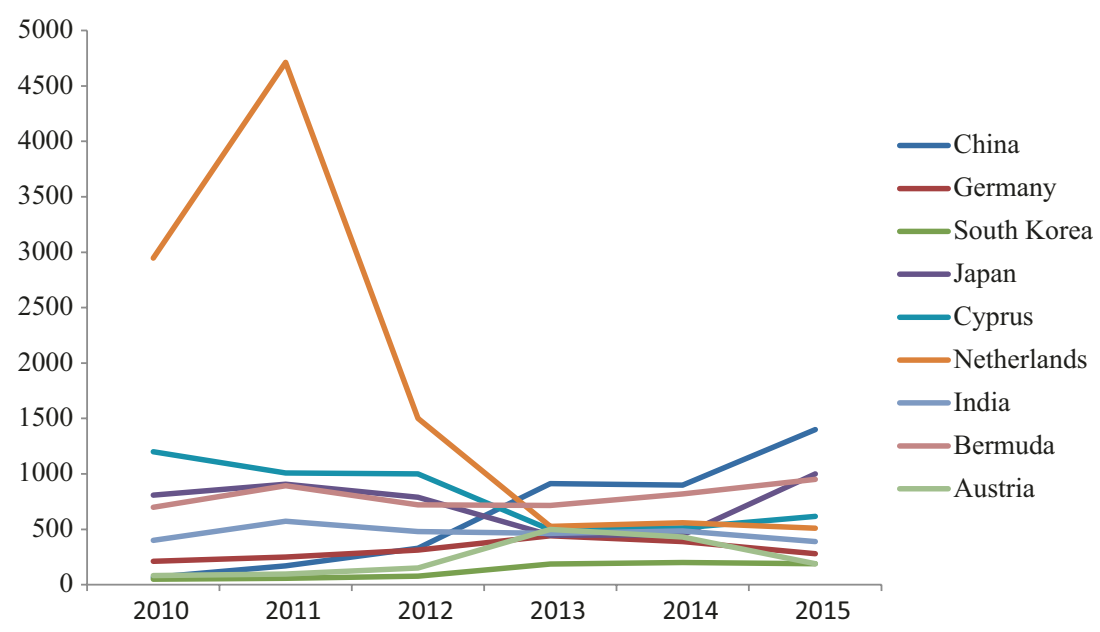

Fig. 8.3 FDI in the Russian Far East by main Asian and non-Asian partners (million USD) (Federal State Statistics Service 2016) 
Korea showed modest growth. Only China breaks this pattern with a clear upward trend across the period in question. In 2015-16, according to Aleksandr Galushka, Minister for the Development of the Far East, Beijing invested USD 2.6 billion in the region (Russia Today 2016). However, Chinese FDI in 2014-15 was significantly lower than the Dutch FDI in 2010-11, which came in connection with Shell's investment in the Sakhalin oil and gas fields.

Bermuda and Cyprus were among the main investors in the Russian Far East in 2014-15 (Kriuchkova et al. 2016). This investment, however, is predominantly of Russian origin: many Russian state corporations and private firms use offshore accounts, registering in various tax havens in order to reduce the tax burden. Whereas this investment is technically classified as foreign, in practice, it is domestic. For 2017, the Far East Investment and Export Agency under the Ministry for the Development of the Far East announced a goal of attracting USD 1.6 billion-again mainly from domestic investors (Fingar 2016).

As seen in Fig. 8.3, China has in recent years been the single biggest investor in the Russian Far East. According to Galushka, Chinese investments have been 'a result of new Far East development mechanisms', such as the ASEZs, the Free Port of Vladivostok, the Far East Development Fund and targeted infrastructural project support, mechanisms 'popular with Chinese businesses' (Russia Today 2016). However, many of the investment projects promised by China after 2014 have never materialized. This is at least partly related to the international sanctions regime and related Chinese apprehensions (Rozman 2016). On the other hand, Moscow and Beijing have been working on developing parallel financial infrastructure 'that will be immune to sanctions' (Gabuev 2016b).

Russia and China have a shared interest in developing the sparsely populated but resource-rich territory of the Russian Far East. The energy sector has been the main driver (see Overland and Kubayeva, Chap. 6, this volume). In 2014, the conclusion of a USD 400 billion contract to build the Power of Siberia pipeline from Irkutsk and Sakha to China was intended to send a message to the West: Russia had alternatives to the European gas market (Dave 2016). The following year, Rosneft signed contracts with China worth over USD 30 billion to supply oil to the Chinese market (Sputnik International 2015). However, economic recession and infrastructure gaps in the two countries have complicated implementation of these huge energy projects (Dave 2016), and negotiations over implementation of both are currently stalled. 
In other sectors, we find some noticeable success stories. For example, over USD 109 million has been invested in a timber plant in Khabarovsk. The Russian-Chinese Fund for Agro-Industrial Development has set a goal of disbursing USD 1.2 billion to the agricultural sector over the three-year period of 2016-18. Further, Chinese firms have invested in a cement plant in Amur Oblast and have expanded their activities in the Sakha Republic and Primorskii Krai (see Min and Kang, Chap. 4, this volume). Finally, although slow progress on the Russian section has raised concerns, the Amur Bridge, connecting Russia's Blagoveshchensk with China's Heihe in Heilongjiang province, is expected to be completed by 2019.

In general, however, it has proven difficult to attract FDI as well as domestic investment in sectors beyond natural resource extraction. While the idea behind introducing the ASEZs was to promote the production and export of more processed goods, the region has few comparative advantages as regards China; these relate mainly to exports of unprocessed raw materials, including energy.

To balance China's dominance in the Russian Far East, Russia has continued cultivating other partners to add more competition for investment in the region's resources. South Korea and especially Japan are viewed as the most promising potential partners here. For South Korea, integration with the Russian Far East is deemed attractive, as it will strengthen connectivity between Eurasia and the Korean Peninsula. For the Korean ambitions to be fulfilled, however, hard infrastructure will need to be put in place in the Russian Far East (Jeh 2015, p.160).

As for Japan, President Putin, addressing the second Eastern Economic Forum in 2016, spoke of this country as Russia's 'natural' economic partner (Sputnik International 2016). According to the Ministry for the Development of the Far East, the volume of Japanese FDI may easily exceed that of China in the near future (Gazeta.ru 2016). If Moscow and Tokyo manage to sign a deal on the Kuril Islands/Northern Territories, it would undoubtedly boost economic cooperation between the two countries. Japan has already sought to expand bilateral economic ties as a tool for reaching a solution to the territorial dispute (The Japan Times 2016). However, as Gilbert Rozman notes, 'a breakthrough with Japan would hint at multipolarity at China's expense, but it likely would not be transformative' (Rozman 2016). Japan will not be able to satisfy Russia's enormous needs in terms of regional FDI. Still, Russia can use Japan as a wild card in its negotiations with China: increased competition between Beijing 
and Tokyo over resources and influence might lead to increased FDI in the Russian Far East. This is not an easy task, though: Japanese investors tend to expect higher standards than their Chinese counterparts when it comes to business climate. According to Satoshi Sakai (2015, p.128), Russia will need to improve its business climate significantly before it can become an attractive destination for Japanese investors.

\section{Concluding Discussion: The Swan, the Pike AND THE CRAWFish}

Moscow's approach to the economic development of the Russian Far East is reminiscent of Ivan Krylov's well-known fable 'The Swan, the Pike and the Crawfish', where the three protagonists all try to pull a cart in a different direction. This is reflected in the government's economic development policies, where different agencies promote divergent agendas and Moscow largely lacks a unified strategy, but also in the contradictory policies of promoting import substitution policies while trying to open up the Russian Far East to foreign investment.

Assessing the development of trade and FDI in the Russian Far East before and after 2014, we find hardly any positive substantial change, except for the increase in Chinese FDI. On the contrary, trade with Russia's main Asian partners has stagnated in volume and declined in value, and FDI remains negligible compared to domestic capital investment. Implementing the ambitious plans for developing the Russian Far East will require substantial foreign investment, but, as noted by Sung Hoon Jeh et al. $(2015$, p.6), pivoting to Asia is, paradoxically enough, hardly attainable without investment from Western countries. And as long as the sanctions regime remains in place, large-scale Western investment will not be forthcoming. Moreover, the Ukraine crisis has led to reallocations in the Russian federal budget, and the Russian Far East has had to take cuts in order for Moscow to push forward with expensive infrastructure projects in Crimea. Instead of unequivocally facilitating an eastward pivot, the Ukraine conflict has complicated the reorientation to the Eastdomestically in Russia as well as internationally.

As to the larger picture, there has hardly been a Russian economic turn to Asia. The Russian Far East remains a small regional actor and cannot be considered yet an internationally important region in terms of its integration in Asian and global markets. Its trade is still mainly oriented towards markets in European Russia; and in economic matters, the Russian 
Far East's double-headed eagle continues to look more to Moscow than to the Pacific.

To a large extent, developments in the Russian Far East reflect the overall economic situation in Russia, which has worsened since 2014. This downturn has been caused partly by external factors (most importantly, the collapse of the global oil price and the international sanctions), and partly by internal factors (hereunder the adoption of import substitution policies). The existence of contradictory regulatory regimes and the lack of a unified Russian Far East economic development strategy exacerbate the situation. Attaining a level of economic cooperation with Asian partners in line with the economic ties that Russia had with the West prior to 2014 is unlikely in the near future.

Russia's efforts to improve the hard infrastructure to facilitate foreign investment in the region have brought some results. Although the overall investment climate in the Far Eastern Federal Okrug has not improved significantly since 2014, the region has become more diversified, with new infrastructure introduced in order to attract investment beyond the industries connected with natural resource extraction. The increase in Russian offshore capital being reinvested in the Russian Far East is a good sign; several new initiatives, such as the creation of the Free Port of Vladivostok and state support for new private projects through the Far East Development Fund, have also contributed to this diversification effect. However, the external benefits are yet to be seen in practice.

Acknowledgements This chapter is based on data gathered for the TIGER (Trade Integration, Geopolitics and the Economy of Russia) research project, financed by the NORRUSS Programme of the Research Council of Norway.

\section{Notes}

1. The year 2010 has been chosen as a starting point for this study because that was the first full year of implementation of the above-mentioned strategy for the development of the Russian Far East.

2. Interviews were conducted with Russia-based experts (partly based in Moscow, partly in Vladivostok). Their fields of expertise cover economy, business climate, transport, infrastructure and other areas related to the economic development of the Russian Far East. Seven experts were interviewed as part of the 'Trade Integration, Geopolitics and the Economy of Russia (TIGER)' project, funded by the Research Council of Norway. Three interviews were conducted in conjunction with the third 'Developing 
Asia-Pacific's Last Frontier' conference in Shanghai. All interviews took place in August-September 2016, under conditions of anonymity.

3. Interview with expert on the Russian Far East, Moscow, 2 September 2016.

4. The following industries have been identified as targets for ASEZs: construction materials, timber processing, fish processing, tourism, metallurgy, the agro-industrial complex, auto parts, logistics, oil and gas, chemistry, and infrastructure (Ministry for the Development of the Far East 2016).

5. The Ministry of Economic Development has, however, been sceptical about the idea of establishing ASEZs, pointing out that previous attempts to promote special economic zones proved unsuccessful and had no impact on economic growth (Lossan 2014).

6. Data retrieved from the World Bank's 'Ease of doing business' webpage for Russia, under section 'Subnational city'-see http://www.doingbusiness. org/data/exploreeconomies/russia. Accessed on 21 February 2017.

7. It is indicative that in 2015 , only one foreign investor was registered with an ASEZ (Gabuev 2015).

8. See http://minvr.ru/activities/toser.php. Accessed on 20 February 2017. The Far East Investment and Export Agency has, however, developed easily accessible instructions and infographics in English—see http://www. investvostok.ru/en/why/\#territorii-operezhayushchego-razvitiya. Accessed on 20 February 2017.

9. Interview with expert from the Russian Far East, Shanghai, 27 September 2016.

10. Russia had been among China's top 15 trade partners from 2010 to 2014, but in 2015 , it fell to 16th position (Fedorinova et al. 2015).

\section{REFERENCES}

Belenets, Patricia. 2016. 'Demographic potential of the Far East: problems and trends', Problems of Economic Transition 58(7-9): 587-97.

Bradshaw, Michael J. 2012. The Russian Far East and Pacific Asia: unfulfilled potential. London: Routledge.

Choi, David. 2016. "“Putin's Bridge" connecting Russia to Crimea might be having issues', Business Insider, 26 September. http://www.businessinsider.com/ putins-bridge-russia-crimea-problems-2016-9? $\mathrm{r}=\mathrm{US} \& I R=\mathrm{T} \& I R=\mathrm{T}$. Accessed on 18 February 2017.

Connolly, Richard and Philip Hanson. 2016. 'Import substitution and economic sovereignty in Russia', Research Paper. London: The Royal Institute of International Affairs. 
Dave, Bhavna. 2016. 'Russia's Asia pivot: engaging the Russian Far East, China and Southeast Asia', RSIS Working Paper 297. Singapore: S. Rajaratnam School of International Studies.

East Russia Magazine. 2015. 'Far East being proactive', September. www.eastrussia.ru/upload/EastRussia_vef.pdf. Accessed on 20 February 2017.

Edovina, Tat'iana and Aleksei Shapovalov. 2015. 'Gossovet sobral plody importozameshcheniia' [The State Council has gathered the fruits of import substitution], Kommersant, 26 November. http://kommersant.ru/doc/2862090. Accessed on 18 February 2017.

European Union External Action. 2016. 'WTO review: EU calls on Russia to abandon import substitution measures', 28 September. https://eeas.europa. $\mathrm{eu} /$ topics/water-diplomacy/10713/wto-review--eu-calls-on-russia-to-abandon-import-substitution-measures_en. Accessed on 18 February 2017.

Federal State Statistics Service. 2016. 'Main indicators'. http://www.gks.ru/ wps/wcm/connect/rosstat_main/rosstat/en/main. Accessed on 18 February 2017.

Fedorinova, Yuliya, Elena Mazneva and Anna Baraulina. 2015. 'Putin's got a new problem with China', Bloomberg, I September. https://www.bloomberg.com/ news/articles/2015-09-01/putin-s-china-turn-hits-potholes-as-trade-dropsmarkets-slide. Accessed on 18 February 2017.

Fingar, Courtney. 2016. 'A distant dream: Putin plans to revitalise Russian Far East', FDI Intelligence, 13 October. http://www.fdiintelligence.com/Locations/ Europe/Russia/A-distant-dream-Putin-plans-to-revitalise-Russian-Far-East. Accessed on 18 February 2017.

Gabuev, Alexander. 2015. 'Povorot v nikuda: itogi aziatskoi politiki Rossii v 2015' [Turn to nowhere: results of Russia's Asian policy in 2015], Moscow Carnegie Center, 29 December. http://carnegie.ru/commentary/2015/12/29/ ru-62369/ioe2. Accessed on 18 February 2017.

Gabuev, Alexander. 2016a. 'Did Western sanctions affect Sino-Russian economic ties?’ Moscow Carnegie Center, 26 April. http://carnegie.ru/2016/04/26/ did-western-sanctions-affect-sino-russian-economic-ties-pub-63461. Accessed on 18 February 2017.

Gabuev, Alexander. 2016b. 'Russian-Chinese relations after the Ukraine crisis', Moscow Carnegie Center, 29 June. http://carnegie.ru/2016/06/29/friendswith-benefits-russian-chinese-relations-after-ukraine-crisis-pub- 63953. Accessed on 18 February 2017.

Gazeta.ru. 2016. 'Minvostokrazvitiia: ob" em iaponskih investitsii mozhet prevysit' kitaiskie' [Ministry for the Development of the Far East: the volume of Japanese investment may exceed the Chinese], 30 December. https://www. gazeta.ru/business/news/2016/12/30/n_9519971.shtml. Accessed on 18 February 2017. 
Guriev, Sergei. 2015. 'Deglobalizing Russia', Moscow Carnegie Center, 16 December. http://carnegie.ru/2015/12/16/deglobalizing-russia-pub-62294. Accessed on 18 February 2017.

The Japan Times. 2016. 'Russia, Japan agree to promote economic cooperation in Russian Far East', 5 November. http://www.japantimes.co.jp/ news /2016/11/05/business/russia-japan-agree-promote-economic-cooperation-russian-far-east/\#.WECOVH0rTbU. Accessed on 18 February 2017.

Jeh, Sung Hoon. 2015. 'Russian Far East development and directions for improvement in Korean-Russian cooperation: Korea's perspective', in International cooperation in the development of Russia's Far East and Siberia, edited by Jing Huang and Alexander Korolev, 144-63. Basingstoke: Palgrave Macmillan.

Jeh, Sung Hoon, Jiyoung Min, Boogyun Kang and Sergey Lukonin. 2015. 'Recent development in the Russian Far East-Baikal Region and its implication', KIEP World Economy Update 5(17): 1-6.

Kremlin.ru. 2015. 'First Eastern Economic Forum', 4 September. http://en. kremlin.ru/events/president/news/50232. Accessed on 18 February 2017.

Kriuchkova, Evgeniia, Oleg Sapozhkov and Tat'iana Edovina. 2016. 'Dal'nii Vostok razmenial rubl' na dvenadtsat" [Far East exchanged one ruble for twelve], Kommersant, 5 May. http://www.kommersant.ru/doc/2979487. Accessed on 21 February 2017.

Labykin, Aleksandr. 2014. 'Dal'nii Vostok gotov k prihodu investorov' [Far East is ready for the arrival of investors], Ekspert Online. http://expert.ru/ 2014/06/23/aziatskie-kompanii-rvutsya-na-dalnij-vostok. Accessed on 21 February 2017.

Lee, Rensselaer and Artyom Lukin. 2015. Russia's Far East: new dynamics in Asia Pacific \& beyond. Boulder, CO: Lynne Rienner.

Lossan, Alexei. 2014. 'Seven large foreign investors are to come to Russian Far East', Russia Beyond the Headlines, 20 September. http://rbth.com/business /2014/09/20/seven_large_foreign_investors_are_to_come_to_russian_ far_east_39979.html. Accessed on 20 February 2017.

Makarov, Igor. 2017. 'Transformation of the economic model in Asia-Pacific region: implications for Russia's Far East and Siberia', in The political economy of Pacific Russia: regional developments in East Asia, edited by Jing Huang and Alexander Korolev, 77-101. Basingstoke: Palgrave Macmillan.

Ministry for the Development of the Far East. 2016. 'Plans and objectives', http://minvr.ru/upload/Ministry\%20\%20Russian\%20Far\%20East\%201.pptx. Accessed on 18 February 2017.

The Moscow Times. 2016. 'Russian-Chinese trade plummets in 2015', 13 January. http://www.themoscowtimes.com/business/article/russian-chinese-tradeplummets-in-2015/555632.html. Accessed on 18 February 2017. 
Rozman, Gilbert. 2016. 'Russian dissatisfaction with China and its limits', China Policy Institute: Analysis. https://cpianalysis.org/2016/04/07/russian-dissatisfaction-with-china-and-its-limits. Accessed on 18 February 2017.

Russia Direct. 2016a. 'The bold plan to turn Vladivostok into a Russian San Francisco', 2 September. http://www.russia-direct.org/analysis/bold-planturn-vladivostok-russian-san-francisco. Accessed on 18 February 2017.

Russia Direct. 2016b. 'Crossing the bridge to the Far East', Moscow: Russia Direct.

Russia Today. 2016. 'China invests \$2.4bn in Russian Far East', 5 July. https:// www.rt.com/business/349524-china-russian-region-investments. Accessed on 18 February 2017.

Sakai, Satoshi. 2015. 'Economic relations between Japan and the Russian Far East', in International cooperation in the development of Russia's Far East and Siberia, edited by Jing Huang and Alexander Korolev, 123-43. Basingstoke: Palgrave Macmillan.

Sputnik International. 2015. 'Rosneft signs contracts with China worth over $\$ 30$ bln',3September.http://sputniknews.com/business/20150903/1026542805. html. Accessed on 18 February 2017.

Sputnik International. 2016. 'Putin's speech at Eastern Economic Forum in Vladivostok', 3 September. http://sputniknews.com/politics/20160903/ 1044918709/putin-eastern-economic-forum.html. Accessed on 18 February 2017.

Turovskii, Rostislav. 2015. 'Delovoi portret Dal'nego Vostoka' [Business portrait of the Far East], EastRussia, 17 September. http://www.eastrussia.ru/material/delovoy-portret-dalnego-vostoka/. Accessed on 21 February 2017.

Vl.ru. 2010. 'Nadezhda Mikheeva: na Dal'nem Vostoke Primor'e poluchaet bol'she vsego investitsii' [Nadezhda Mikheeva: Primorye receives the greatest amount of investment in the Far East], 7 December. http://www.newsvl.ru/ biznes/2010/12/07/investprim. Accessed on 18 February 2017.

WTO. 2016. 'Trade policy review: Russian Federation'. https://www.wto.org/ english/tratop_e/tpr_e/s345_e.pdf. Accessed on 18 February 2017.

Zubacheva, Kseniia. 2016. 'Next stage in Russian economic development is in the Far East', Russia Direct, 30 September. http://www.russia-direct.org/company-news/moscow-vladivostok-next-stage-russian-economic-development. Accessed on 18 February 2017. 
Open Access This chapter is licensed under the terms of the Creative Commons Attribution 4.0 International License (http://creativecommons.org/licenses/ by $/ 4.0 /$ ), which permits use, sharing, adaptation, distribution and reproduction in any medium or format, as long as you give appropriate credit to the original author(s) and the source, provide a link to the Creative Commons license and indicate if changes were made.

The images or other third party material in this book are included in the book's Creative Commons license, unless indicated otherwise in a credit line to the material. If material is not included in the book's Creative Commons license and your intended use is not permitted by statutory regulation or exceeds the permitted use, you will need to obtain permission directly from the copyright holder. 